UDC 633.353.2:631.576

\title{
SEED AND RESIDUE YIELDS AND NUTRITIONAL VALUE OF SELECTED BROAD BEAN VARIETIES
}

\author{
J. Franczuk, Dr.Sc. ${ }^{1}$ \\ ORCID ID: 0000-0002-8440-850X \\ R. Rosa Dr.Sc. ${ }^{1}$ \\ ORCID ID: 0000-0001-6344-538X \\ Myslinska M., M. Sc. ${ }^{1}$ \\ ORCID ID: 0000-0001-6249-741X \\ Slonecka D., M. Sc. ${ }^{1}$ \\ ORCID ID:0000-0002-8696-2774 \\ Hajko L., M. Sc. ${ }^{1}$ \\ ORCID ID: 0000-0001-5293-8402 \\ Dydiv O., Cand. Sc. ${ }^{2}$ \\ ORCID ID: 0000-0003-4155-5945 \\ ${ }^{1}$ Siedlce University of Natural Sciences and Humanities \\ ${ }^{2}$ Lviv National Agrarian University
}

https://doi.org/10.31734/agronomy2020.01.117

Франчук Ж., Роса Р., Мислінська М., Слонецька Д., Хайко Л., Дидів О. Урожайність, харчова цінність і маса післяжнивних решток сортів бобу великонасінного

Біб овочевий є прекрасним джерелом білка, вуглеводів, основних мінералів, вітамінів та антиоксидантів, харчових волокон та інших корисних сполук для здоров'я людини. Біб радять вживати при хворобах системи кровообігу. Регулює також діяльність травної системи - завдяки клітковині він значно прискорює процес метаболізму, тому його охоче застосовують у дієтах. Вегетативні рештки після збирання врожаю використовують у тваринництві, оскільки це чудовий корм для збільшення надоїв і ваги. Для домашньої птиці бобову надземну масу висушують, перетирають і додають у мішанки.

У Польщі цей овоч набирає все більшої популярності. Врожайність насіння овочевих бобів, вирощених для раннього врожаю, залежить від багатьох чинників, включаючи вибір правильного сорту.

Польовий дослід був проведений у Центрально-Східній Польщі на сільськогосподарській дослідній станції в Завадах на грунті Лувісол. Метою експериментальних досліджень було порівняння врожаю, поживної цінності й кількості післяжнивних решток трьох сортів бобу великонасінного - Windsor Biały, Bizon та Bacchus. Дослід закладено у трьох повтореннях блоками. Бобові рослини збирали у фазі молочної стиглості. Після збору визначали врожайність бобів та насіння. На основі співвідношення ваги насіння до ваги бобів було обчислено біологічні показники врожаю. Вимірювали довжину та ширину насіння, їхню товщину біля зародка. У насінні визначали суху речовину, L-аскорбінову кислоту, загальний цукор, кальцій та фосфор. Після збирання бобів визначали кількість післяжнивних решток бобу великонасінного.

Дослідження показали, що сорт Bizon доцільно рекомендувати для вирощування в кліматичних умовах Східно-Центральної Європи, оскільки врожайність його була найвища. Сорт Bizon також характеризувався найбільшим вмістом цукру та фосфору. Серед сортів Windsor Biały дав найбільшу кількість післяжнивних решток, що $\epsilon$ багатим джерелом азоту для рослин, котрі вирощуватимуть після бобів.

Ключові слова: Vicia faba L. Var. Major, сорт, харчова цінність, післяжнивні рештки.

Franczuk J., Rosa R., Myslinska M., Slonecka D., Hajko L., Dydiv O. Seed and residue yields and nutritional value of selected broad bean varieties

Broad beans are an excellent vegetable source of protein, carbohydrates, essential minerals, vitamins and antioxidants, dietary fibre, and other health-promoting compounds. Beans are recommended for use in case of diseases of the circulatory system. It also regulates the activity of the digestive system - thanks to fiber, it significantly speeds up the process of metabolism, so it is readily used in diets. Vegetative residues after harvest are used in animal husbandry, as it is an excellent feed to increase milk yield and weight. For poultry, the above-ground bean mass is dried, ground and added to the mixes.

In Poland, this vegetable is gaining more and more popularity. The yield of broad beans grown for an early harvest is determined by many factors, and among others, the selection of the right cultivar is particularly important.

The field experiment was carried out in Central Eastern Poland, at the Agricultural Experimental Station in Zawady, on luvisol soil. The purpose of the research was to compare the yield and nutritional value of three broad bean varieties: 
'Windsor Bialy', 'Bizon', and 'Bachus', and the amounts of their postharvest residues. The experiment was founded in a split-block design with three replications. Broad bean plants were harvested at the milk stage of the seeds. After the harvest, the yields of pods and seeds were determined. The biological performance of the crop was calculated on the basis of the seed weight to pod weight ratio. Additionally, the length and width of the seeds and their thickness at the hilum were measured. In broad bean seeds, the content of dry matter, L-ascorbic acid, total sugars, protein, calcium, and phosphorus were determined. After the harvest, the yield of the residues of broad bean plants was calculated.

Taking into account the biological performance of the crop varieties, it was found that due to its yield 'Bizon' should be recommended in the climatic conditions of Central Eastern Europe. The 'Bizon' cultivar also contained the highest total sugar and phosphorus content. Among the varieties, 'Windsor bialy' produced the highest amount of stalks, which would be a rich source of nitrogen for plants grown after broad bean.

Key words: Vicia faba L. var. major, cultivar, yielding, nutritive value, postharvest residues.

Problem setting. Broad bean is one of the oldest cultivated plants, known and grown for several thousand years. Traces of prehistoric broad bean crops were found in Asia Minor, as well as in Southern, Western, and Central Europe [9]. It requires early sowing which, depending on climatic regions, should be done from the end of March to mid April. Due to large moisture resources in the soil, early sowing ensures good and even germination.

The yield of field vegetables, grown for an early harvest, is determined by many factors, and among others, the selection of the right cultivar is particularly important [12]. Seeds of the Vicia faba L. Var. Major varieties are used at the stages of incomplete maturity, also called technological, and dry seed maturity. Seeds of complete, or dry maturity are used for direct consumption and for food processing like freezing and preserving. Dry seeds are used to make flour for bread and for starch jelly and pasta manufacturing. Broad bean vegetable seeds are considered an important source of protein, carbohydrates, essential minerals, vitamins and antioxidants, dietary fibre, and other health-promoting compounds [10]. Broad bean seeds, both not fully ripe and dry ones, are valued primarily as a source of easily digestible plant protein, carbohydrates, vitamins, and minerals $[6 ; 8]$.

Analysis of recent research and publications. The global production volume of broad bean and horse bean for dry seeds in 2018 was 4.9 million tonnes, of which around 930,000 tonnes in Europe. The largest producer in the world was China (1.8 million tonnes), with the UK (402 thousand tonnes) being the biggest one in Europe. In 2018, production volumes in Poland and Ukraine were 280 and 7.7 thousand tonnes, respectively [2].

Postharvest residues of plants may be a valuable additive to animal feed, and, when ploughed in, a valuable organic fertilizer $[13 ; 14]$. The nutritive effects of incorporated postharvest residues are lower than those of the entire biomass of plants. However, even the residues have a beneficial effect on the physical, chemical. And biological properties of the soil and consequently have a positive effect on the yield of successive plants. The yield effect of postharvest residues is visible not only in the first year after ploughing them in, but also in the following years [4]. Although broad bean seeds are generally considered to have a high nutritional value, there are some differences between varieties in yields and in nutrient content, resulting from genetic characteristics.

Problem statement. Thus, it is necessary to select the best-yielding cultivar, with high nutrient content. The purpose of the studies was to compare yields, nutritional value, and the amounts of residues of three broad bean varieties.

The main materials and methods. Field experiment was conducted in Central Eastern Poland $\left(52^{\circ} 03 \mathrm{~N}, 22^{\circ} 33 \mathrm{E}\right)$ on Luvisol soil [16]. The soil was characterized by a humus layer $30-40 \mathrm{~cm}$ deep, the average organic carbon content of $2.1 \%$, and soil $\mathrm{pH}$ in $\mathrm{H}_{2} \mathrm{O}$ of 5.73. The total macronutrient content in 1 $\mathrm{dm}^{3}$ of the soil was: $11 \mathrm{mg}$ of $\mathrm{NH}_{4}-\mathrm{N} ; 6 \mathrm{mg}$ of $\mathrm{NO}_{3}$ $\mathrm{N} ; 73 \mathrm{mg}$ of $\mathrm{P}_{2} \mathrm{O}_{5} ; 65 \mathrm{mg}$ of $\mathrm{K}_{2} \mathrm{O} ; 380 \mathrm{mg}$ of $\mathrm{Ca} ; 40$ $\mathrm{mg}$ of $\mathrm{Mg}$.

Three varieties of broad bean were studied in the experiment: 'Windsor Bialy', 'Bizon', and 'Bachus'. The experiment was founded in three replications, in a split-block design. The area of a plot, covered with plants, was $15 \mathrm{~m}^{2}$.

The soil was prepared at the beginning of April in accordance with agricultural recommendations for this crop species. Mineral fertilizers were applied to bring the nutrient content in the soil to the level optimal for this plant: $\geq 30 \mathrm{mg} \mathrm{N} \cdot \mathrm{dm}^{-3} ; 70 \mathrm{mg} \mathrm{P} \cdot \mathrm{dm}^{-3}$;

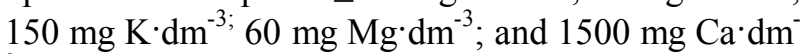
3 . The seeds of broad bean were planted after 10 April in spacing of $50 \mathrm{~cm} \times 10 \mathrm{~cm}$. Immediately after sowing, polypropylene non-woven fabric (PP $17 \mathrm{~g} \cdot \mathrm{m}^{-}$ ${ }^{2}$ ) was used to cover the plants for three weeks. Plots were weeded and plants were protected from pests and diseases. The broad bean was harvested manually at the beginning of July, at the milk stage of the seeds. 
After harvesting, the yield of pods and the yield of seeds were calculated.

On the basis of the ratio of seed weight to pod weight, the biological performance of the crop was determined. From each combination, 100 pods were sampled to assess the biometric characteristics of seeds. Then, pods were shelled, and from each sample, 100 seeds were randomly selected. The length and width of the seeds and the thickness at the hilum were measured. From each combination, samples of seeds for chemical analysis were also collected to determine the following content: dry matter by drying to constant mass at $105^{\circ} \mathrm{C}$; L-ascorbic acid using the Tillmans method [11]; total sugars by the LuffSchoorl method [1]; protein by the Kjeldahl method (at a factor of 6.25), calcium by flame photometry, and phosphorus by the colorimetric molybdenum blue method with vanadium. After harvesting, the yield of dry matter of postharvest stalks was determined.

The significance of differences was determined with Tukey's test at the significance level of $p \leq 0.05$. All the calculations were performed with the Statistica software (version 10, Statsoft, USA).

Among the cultivated varieties of broad bean, the greatest yield was produced by 'Bizon' (Table 1). Its pod yield was $12.0 \%$ higher than that of 'Windsor Bialy' and $19.2 \%$ higher than that of the 'Bachus' cultivar. The yield of fresh seeds of the 'Bizon' cultivar was significantly greater than the seed yield of 'Bachus', with the difference of 23. \%. The seed yield of the 'Windsor Bialy' cultivar was $13.1 \%$ smaller, but it was not significantly different from that of 'Bizon'. Comparing the yield of six varieties, including 'Bachus' and 'Windsor Bialy', and three lineages, Łabuda [9] found that' 'Bachus' and "Jankiel Bialy" produced a fairly stable yield of pods and seeds. Suso et al. [15] reported that the yield of broad bean was dependent on a variety of factors like genetic traits, the withering of young pods as well as _rimordial and seeds, and attempts to obtain beans of the appropriate size. The biological performance of the broad bean varieties did not vary much and ranged from $30.09 \%$ for 'Bachus' to $31.69 \%$ for 'Bizon'.

There were no significant differences between the varieties in the length and width of seeds (Table 2). The seeds of the 'Bizon' cultivar were the longest, and of 'Bachus' the widest. However, significant differences were found in the thickness of the seeds measured at the hilum. The seeds of the 'Bizon' and 'Bachus' varieties were significantly thicker than of 'Windsor Bialy'. The difference was 0.06 and 0.05 $\mathrm{cm}$, respectively. According to Jadczak et al. [5], who assessed yield capacity of broad bean varieties, 'Bachus' had the longest pods and the highest number of seeds, which were also the longest, thickest, and widest.

The highest total sugar content was found in the seeds of the 'Bizon' cultivar (Table 3). It was greater than the sugar content of the 'Windsor Bialy' cultivar and significantly higher than of 'Bachus'. The seeds of the varieties did not differ significantly in the content of dry matter, protein, and L-ascorbic acid. Seeds of 'Bachus' contained the most dry matter, with the highest amounts of protein in 'Bizon' and 'Windsor Bialy', and L-ascorbic acid in 'Windsor Bialy'.

Table 1

Yield of broad bean (average for the years of research)

\begin{tabular}{|l|c|c|c|}
\hline \multicolumn{1}{|c|}{ Cultivar } & $\begin{array}{c}\text { Pod yield } \\
\left(\mathrm{t} \cdot \mathrm{ha}^{-1}\right)\end{array}$ & $\begin{array}{c}\text { Seed yield } \\
\left(\mathrm{t} \cdot \mathrm{ha}^{-1}\right)\end{array}$ & $\begin{array}{c}\text { Biological productivity of } \\
\text { yield (\%) }\end{array}$ \\
\hline 'Windsor Bialy' & $13.81 \mathrm{a}^{*}$ & $4.37 \mathrm{ab}$ & 31.64 \\
\hline 'Bizon' & $15.87 \mathrm{~b}$ & $5.03 \mathrm{~b}$ & 31.69 \\
\hline 'Bachus' & $12.83 \mathrm{a}$ & $3.86 \mathrm{a}$ & 30.09 \\
\hline Mean & 14.17 & 4.42 & 31.14 \\
\hline ANOVA & 16.601 & 8.480 & - \\
\hline$F$-value & 0.011 & 0.036 & - \\
\hline$p$ & 1.92 & 1.02 & - \\
\hline LSD $_{0.05}$ & \multicolumn{5}{|l}{} \\
\hline
\end{tabular}

*Figures followed by different letters in columns differ significantly at $p \leq 0.05$. 
Biometric parameters of broad bean seeds (average for the years of research)

\begin{tabular}{|c|c|c|c|}
\hline Cultivar & $\begin{array}{c}\text { Seed length } \\
(\mathrm{cm})\end{array}$ & $\begin{array}{c}\text { Seed width } \\
(\mathrm{cm})\end{array}$ & $\begin{array}{c}\text { Seed thickness } \\
(\mathrm{cm})\end{array}$ \\
\hline 'Windsor Bialy' & 2.28 & 1.79 & $0.97 \mathrm{a}^{*}$ \\
\hline 'Bizon' & 2.40 & 1.81 & $1.03 \mathrm{~b}$ \\
\hline 'Bachus' & 2.35 & 1.85 & $1.02 \mathrm{~b}$ \\
\hline Mean & 2.34 & 1.82 & 1.01 \\
\hline ANOVA & 3.499 & 1.283 & 8.676 \\
\hline$F$-value & $>0.05$ & $>0.05$ & 0.035 \\
\hline$p$ & $\mathrm{NS}^{\#}$ & $\mathrm{NS}$ & 0.05 \\
\hline LSD $_{0.05}$ & \multicolumn{5}{|l}{} \\
\hline
\end{tabular}

*Figures followed by different letters in columns differ significantly at $p \leq 0.05$;

\# NS - not significant.

The content of selected nutrients in broad bean seeds (average for the years of research)

\begin{tabular}{|l|c|c|c|c|}
\hline \multicolumn{1}{|c|}{ Cultivar } & $\begin{array}{c}\text { Dry mater } \\
(\%)\end{array}$ & $\begin{array}{c}\text { Protein } \\
\left(\mathrm{g} \cdot 100 \mathrm{~g}^{-1} \mathrm{f} . \mathrm{m} .\right)\end{array}$ & $\begin{array}{c}\text { Total sugars } \\
\left(\mathrm{g} \cdot 100 \mathrm{~g}^{-1} \mathrm{f} . \mathrm{m} .\right)\end{array}$ & $\begin{array}{c}\text { L-ascorbic acid } \\
\left(\mathrm{mg} \cdot 100 \mathrm{~g}^{-1} \mathrm{f} . \mathrm{m} .\right)\end{array}$ \\
\hline 'Windsor Bialy' & 19.41 & 6.86 & $2.10 \mathrm{ab}$ & 14.95 \\
\hline 'Bizon' & 19.37 & 6.86 & $2.13 \mathrm{~b}$ & 14.35 \\
\hline 'Bachus' & 19.48 & 6.61 & $1.87 \mathrm{a}$ & 14.16 \\
\hline Mean & 19.42 & 6.78 & 2.03 & 14.49 \\
\hline ANOVA & 0.022 & 0.438 & 8.246 & 1.426 \\
\hline$F$-value & $>0.05$ & $>0.05$ & 0.038 & $>0.05$ \\
\hline$p$ & $\mathrm{NS}$ & $\mathrm{NS}$ & 0.25 & $\mathrm{NS}$ \\
\hline LSD $_{0.05}$ & \multicolumn{5}{|l}{} \\
\hline
\end{tabular}

*Figures followed by different letters in columns differ significantly at $p \leq 0.05$;

\# NS - not significant.

The most calcium was found in the seeds of the 'Windsor Bialy' cultivar and phosphorus in 'Bizon' (Table 4). In a significant way, seeds of the Bacchus cultivar contained the least calcium and of 'Windsor Bialy' the least phosphorus. Examining the nutritional and dietary value of broad bean new varieties, Grela et al. [3] found that those, grown and bred in recent years, had similar content of nutrients, including total protein.

The varieties of broad bean differed significantly in the amount of postharvest residues (Fig. 1). The least of them was produced by the 'Bizon' cultivar, and the most by 'Windsor Bialy'. The postharvest residues of broad bean plants were particularly valuable due to the high content of nitrogen fixed from the atmosphere by legume bacteria.

Kulig et al. [7] reported that the average nitrogen content in the aboveground parts of horse bean, Vicia faba L. Var. Minor, a plant closely related to broad bean, was $2.57 \%$ (from $2.08 \%$ to $2.99 \%$ ). Assuming that average nitrogen content in broad bean is similar to that in horse bean, postharvest residues of the 'Bizon' cultivar produce approximately $224.5 \mathrm{~kg}$, 'Bachus' about $262.9 \mathrm{~kg}$, and 'Windsor Bialy' about $282.7 \mathrm{~kg}$ of nitrogen. Ploughing the residues of these plants into the soil allows reducing the amounts of mineral nitrogen, applied to successive plants. 
The content of selected minerals in broad bean seeds (average for the years of research)

\begin{tabular}{|l|c|c|}
\hline Cultivar & $\begin{array}{c}\text { Calcium } \\
\left(\mathrm{mg} \cdot 100 \mathrm{~g}^{-1} \mathrm{~d} . \mathrm{m} .\right)\end{array}$ & $\begin{array}{c}\text { Phosphorus } \\
\left(\mathrm{mg} \cdot 100 \mathrm{~g}^{-1} \mathrm{~d} . \mathrm{m} .\right)\end{array}$ \\
\hline 'Windsor Bialy' & $37.60 \mathrm{~b}$ & $125.40 \mathrm{a}$ \\
\hline 'Bizon' & $36.28 \mathrm{ab}$ & $126.80 \mathrm{~b}$ \\
\hline 'Bachus' & $35.02 \mathrm{a}$ & $126.26 \mathrm{ab}$ \\
\hline Mean & 36.30 & 126.15 \\
\hline ANOVA & 7.106 & 10.220 \\
\hline$F$-value & 0.048 & 0.027 \\
\hline$P$ & 2.44 & 1.30 \\
\hline LSD $_{0.05}$ & & \\
\hline
\end{tabular}

*Figures followed by different letters in columns differ significantly at $p \leq 0.05$.

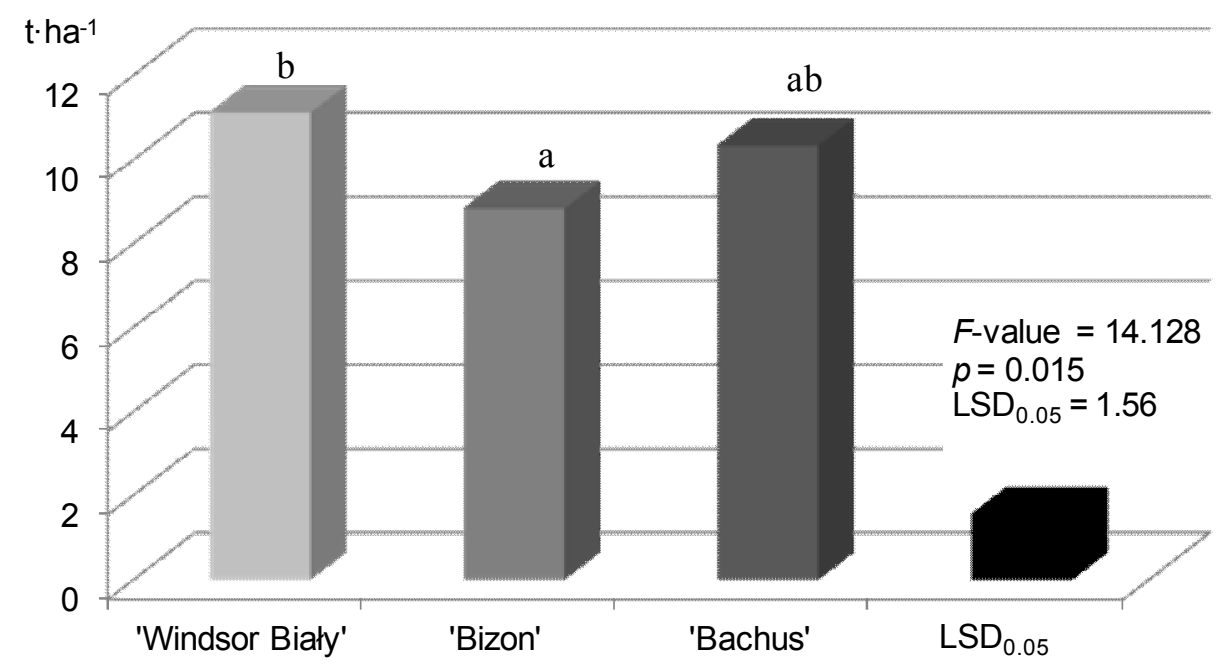

Fig. 1. Yield of dry matter of broad bean post-harvest residues (average for the years of research).

Conclusions. Regardless of the cultivar, broad bean seeds can be a valuable nutritional and dietary product in human nutrition. Due to its high yield, 'Bizon' is among broad bean varieties recommended for growing in the climatic conditions of Central Eastern Europe. Compared to 'Windsor Bialy' and 'Bachus', it contains the highest amounts of sugar and phosphorus, and similar content of dry matter, protein, L-ascorbic acid and calcium. Among the varieties, 'Windsor Bialy' produces the most postharvest residues, a rich source of nitrogen for successive plants.

\section{References}

1. European Union. 2009. Commission Regulation NO 152/2009. Off. J. Eur. Union L54:1-130.

2. FAOSTAT 2020. Broad bean and horse bean production in 2018, Crops/Regions/World list/Production
Quantity (pick lists). UN Food and Agriculture Organization, Corporate Statistical Database. Retrieved 10 March 2020 .

3. Grela E. R., Makaruk J., Czech A., Panayiotou P. P. 2003. Wartość odżywcza i dietetyczna nasion nowych odmian bobu (Vicia faba var. major) [Nutritive and dietary value of new sorts of broad bean seeds (Vicia faba var. major]. Żywienie Człowieka i Metabolizm. 3-4: 919-924.

4. Jabłońska-Ceglarek R., Franczuk J., ZaniewiczBajkowska A., Rosa R. 2002. The effect of summer catch crops on yielding and chosen elements of nutritious value of onion and red beet. Folia Horticulturae. 14(2): 11-23.

5. Jadczak D., Grzeszczuk M., Rekowska E. 2005. The estimation of yielding of new broad bean cultivars in the cultivation for green seeds. Zeszyty Naukowe AR we Wrocławiu. 515: 217-221.

6. Jensen E. S., Peoples M. B., Hauggaard-Nielsen H. 2010. Faba bean in cropping systems. Field Crops 
Research. 115: 203-216. Doi.org/10.1016\%2Fj.fcr.2009. 10.008

7. Kulig B., Szafrański W., Zając T. 2004. Yielding of catch crop cultivated after field bean and organic carbon contents in the soil dependent on weather conditions. Acta Agrophysica. 3(2): 307-315.

8. Kulka K., Grzesiuk S. 1978. Białka nasion roślin strączkowych. Roczniki Nauk Rolniczych. 1(166): 53-90.

9. Łabuda H. 2012. Flowering and characteristics of useful traits of some faba bean (Vicia faba L. var. major Harz) cultivars and breeding lines. Acta Agrobotanica. 65(4), 2012: 139-148. Doi.org/10.5586/aa.2012.031.

10. Ntatsi G., Gutiérrez-Cortines M.E., Karapanosa I., Barros A., Weiss J., Balliu A., Santos Rosa E.A., Savvasa D. 2018. The quality of leguminous vegetables as influenced by preharvest factors. Scientia Horticulturae. 232: 191-205. Doi.org/10.1016/j.scienta.2017.12.058.

11. PN-A-04019 1998. Food products Determination of vitamin C content. - Produkty spożywcze - Oznaczanie zawartości witaminy C [in Polish].
12. Rekowska E. 2007. The influence of flat covers and methods of clove planting on yielding of Garlic cultivated for bunching harvest. Roczniki AR w Poznaniu, CCCLXXXIII, Ogrodnictwo. 41: 589-593.

13. Singh A. K., Bharati R. C., Manibhushan N. C., Pedpati A. 2013. An assessment of faba bean (Vicia faba L.) current status and future prospect. African Journal of Agricultural Research. 8: 6634-6641. Doi. 10.5897/AJAR2013.7335.

14. Stagnari F., Maggio A., Galieni A., Pisante M. 2017. Multiple benefits of legumes for agriculture sustainability: an overview. Chemical and Biological Technologies in Agriculture. 4:2. Doi.org/10.1186/s40538016-0085-1.

15. Suso M. J., Moreno M. T., MondragaoRodrigues F., Cubero J. I. 1996. Reproductive biology of Vicia faba: role of pollination conditions. Field Crops Research. 46: 81-91.

16. World Reference Base for Soil Resources 2014. 2015. World Soil Resource Reports FAO 106, Rome.

Стаття надійила 29.03.2020 